\title{
Travma ve Göç: Bir Gözden Geçirme
}

\author{
Görkem DERINN ${ }^{1}$
}

Atıf/C): Derin, Görkem, Travma ve Göç: Bir Gözden Geçirme, Artuklu İnsan ve Toplum Bilim Dergisi 2020/5 (2), 46-55.

Öz

Ülkemizde ve tüm dünyada hem göçmenlere hem de göç olgusuna yönelik klinik psikoloji ve psikiyatri disiplinleri tarafından yürütülen bilimsel araştırma ve uygulamalara olan akademik ilgi artarak devam etmektedir. Toplumsal değişimin neden olduğu kolektif bir eylem olarak göç; psikolojik, sosyolojik, ekonomik ve bireysel sebeplerle bir yerden başka bir yere yapılan, kısa, orta veya uzun vadede geriye dönüş veya sürekli yerleşim hedefi güden coğrafik, kültürel ve toplumsal bir yer değiştirme hareketidir. Göçmenin kendi ülkesinden ya da ikamet ettiği bölgeden ayrılmasının birtakım nedenleri olduğu gibi göç ettiği yeri ya da toplumda karşılaşacağı tutum ve davranışları öngörmek oldukça güçtür. Göç süreci bazen göçmelerin öngördüğü üzere pozitif gelişmelerle ilerlemekte bazen ise beklentilerin aksine negatif yönde değişimlerin gerçekleştiği durumlar da ortaya çıkabilmektedir. Göçmenlerin sıkça karşılaştıkları olumsuz yaşam deneyimleri arasında sağlık ve eğitim hizmetlerine erişim eksikliği, ayrımcılık, sosyal dışlanma, çalışma izni edinmede yaşanan zorluk, kültür şoku, işsizlik, aile üyelerinden uzak kalma ve göç edilen yerde kendini yalnız hissetme yer almaktadır. Bu travmatik yaşantılar neticesinde göçmenler, sadece geldikleri yeni kültür ve normlarla karakterize olan toplumla uyum sorunu yaşamamakta, aynı zamanda travma sonrası stres bozukluğu, dissosiyatif bozukluk ve somatoform bozukluk gibi kronik psikiyatrik rahatsızlıklar da geliştirebilmektedir. Göçmenlere dair birçok devletin izlediği strateji ve politikalar, bu grubun topluma olan entegrasyonlarının en kısa sürede sağlanması ve psikolojik desteğin uygun koşullar altında verilmesi temel alınarak planlanmakta ve yürütülmektedir.

Anahtar Kelimeler: Travma; göç; travma sonrası stres bozukluğu; dissosiyasyon; dissosiyatif bozukluk

\section{Trauma and Migration: A Review}

Atıf/C): Derin, Görkem, Trauma and Migration: A Review, Artuklu Human and Social Science Journal 2020/5 (2), 46-55.

\section{Abstract}

Academic interest in scientific research and applications conducted by clinical psychology and psychiatry disciplines for both immigrants and the phenomenon of immigration in our country and all over the world continues to increase. Migration as a collective action caused by social change; It is a geographical, cultural, and social displacement movement that is made from one place to another for psychological, sociological, economic, and individual reasons, and aims at the return or permanent settlement in the short, medium or long term. As there are some reasons for the immigrant to leave his country or region of residence, it is very difficult to predict the place of migration or the attitudes and behaviors he will encounter in the society. The migration process sometimes progresses with positive developments beyond what migrations anticipate, and sometimes there are situations where negative changes occur contrary to expectations. Among the negative life experiences that immigrants frequently encounter; lack of access to health and education services, discrimination,

\footnotetext{
${ }^{1}$ Uzman Psk., İstanbul Üniversitesi-Cerrahpaşa, Adli Tıp ve Adli Bilimler Enstitüsü, Sosyal Bilimler ABD, Gorkem.derin@gmail.com, ORCID: orcid.org/0000-0002-9527-3110.

Geliş/Received: 27.10.2020, Kabul/Accepted: 19.11.2020
} 


\section{G. DERIN}

social exclusion, difficulty in obtaining work permits, culture shock, unemployment, staying away from family members, and feeling lonely in the place of migration. As a result of these traumatic experiences, immigrants not only experience a problem of adaptation to the society, which is characterized by the new culture and norms they come from but also develop chronic psychiatric disorders such as post-traumatic stress disorder, dissociative disorder, and somatoform disorder. The strategies and policies pursued by many states regarding immigrants are planned and carried out on the basis of ensuring the integration of this group into society as soon as possible and providing psychological support under appropriate conditions.

Keywords: Trauma; migration; post-traumatic stress disorder; dissociation; dissociative disorder.

\section{GİRIŞ}

Klinik psikoloji, psikiyatri, sosyoloji ve antropoloji başta olmak üzere birçok disiplin, geçmişten günümüze uzanan geniş bir zaman diliminde göç olgusunu aydınlatmaya ve göçmenlerin sıklıkla deneyimlediği sorunlara dair çözüm önerileri geliştirmeye devam etmektedir. Ulusal ve uluslararası düzeyde göç alan ülkeler daha çok bu sürecin sosyoekonomik yansımalarına ilişkin endişe duymaktayken, göç veren ülkeler ise genç nüfusun azalması ve kendi toplumları için yararlı olabilecek nitelikteki vatandaşların diğer ülkeleri tercih etmelerine yönelik çözüm arayışına girmektedir (Gheasi ve Nijkamp, 2017: 31). Göç sürecinin beraberinde getirdiği kayıplar, kültür şoku, sağlık ve eğitim hizmetlerine erişim eksikliği, ayrımcılık, damgalanmaya sıkça maruz kalınması, çalışma izninin olmaması ya da bu izni almada yaşanan zorluklar, göçmenlerce travmatik yaşantılar olarak hissedilebilmektedir. Zorla kendi ülkesinden ayrılmak zorunda kalan göçmenler savaş, çatışma ve kaotik bir ortam ile identik olan anavatanlarından ayrılsalar dahi bu yolculuk genellikle diğer travmatik olaylara maruz kalabilecekleri uzun ve meşakkatli bir sürecin başlangıcını oluşturmaktadır. Kendi iradeleri dışında göç etmeye zorlanan bireyler, yeni ülkeye geldiklerinde toplumla uyum sorunu yaşayabilmekte ve yeni sosyal çevre ile entegre bir kimlik oluşturma sürecine girebilmektedir (Wirtgen, 2009: 21). Hem göç süreci hem de göç sonrasında ortaya çıkabilen psikolojik sorunlar, göçmenlerde travma kökenli psikopatolojilerin gelişmesine sebep olabilmektedir (Laban ve ark., 2008: 507; Schouler-Ocak, 2015: 5). Bu çalışmada psikolojik travma açısından göç olgusunun değerlendirilmesi amaçlanmaktadır.

\section{Göç Olgusu ve Göçmen Kavramı}

Toplumun sosyal, psikolojik, siyasal ve kültürel dinamikleriyle yakından ilişkili olan ve bu dinamikleri önemli ölçüde etkileyen kümülatif bir süreci kapsayan göç, insanların kendi gerekçelerine bağlı olarak yaşadıkları yerden başka bir yere doğru mekân ya da yerleşim birimini değiştirmesi olarak tanımlanmaktadır. Bireyler ve toplumlar üzerinde majör değişimler yaratabilmesi sebebiyle göç, psikologlardan sosyologlara, antropologlardan ekonomistlere kadar uzanan geniş bir mesleki kitle tarafından bilimsel açıdan oldukça yoğun ilgi görmektedir (Şentürk, 2019: 19). Son yıllarda hem ulusal ve uluslararası göçe katılan kişilerin hem de sosyo-psikolojik alanda yapılan göç temelli çalışmaların sayısı önemli ölçüde artış göstermektedir (Giddens ve Sutton, 2016: 109). Göçün gerçekleşmesi için dört temel bileşenin bir arada bulunması gerekmekte olup bu bileşenler aşağıda sıralanmaktadır:

1. Göç sürecinde aktif olarak bulunacak aktör veya aktörler,

2. Aktörleri göç etmeyi düşünmeye ve bu eylemde bulunmaya zorlayan sosyal ve çevre kaynaklı sebepler,

3. Göç etmek için tercih edilecek alternatif bir yerin/mekânın olması,

4. Göç sürecinde ya da sonrasında ortaya çıkan ekonomik, biyolojik, sosyal, kültürel ve psikolojik nitelikteki karşılaşılması olası riskleri ve belirsizlikleri göze almak. 
Genel olarak bu bileşenler bir bütünü oluşturduğu zaman göç kararı alınmakta ve bu süreç gerçekleşmektedir (Yazıcı, 2019: 77).

Kişilerin veya grupların kendi iradeleri ya da iradesi dışında yer değiştirmesi ile gidilen yer ve mesafe gibi birçok özellik, göç sürecinin temel yapı taşlarını oluşturmaktadır (Ekici ve Tuncel, 2015: 14). Göç olgusu; gidilen yer ve mesafe (iç ve diş göç), yer değiştirme eylemini gerçekleştiren kişi sayısı (bireysel ve kitlesel göç), başka bir bölge ya da ülkeye gitme sürecindeki iradenin boyutu (gönüllü ve zorunlu göç), ulaşılan yerde kalma süresi (geçici ve sürekli göç) ve bu sürecin legal prosedüre uyumu (düzenli ve düzensiz göç) olmak üzere beş farklı şekilde sınıflandırılmaktadır. Gidilen yer ve mesafe açısından "iç göç", kişi ve toplulukların belli sebeplerle ülke sınırları içerisinde bir yıldan fazla olmak şartıyla yer değiştirmesi olarak tanımlanmaktadır. İç göçün temel sebepleri arasında eğitim, çalışma yeri değişikliği, emeklilik ve boşanma gelmektedir (Otoiu, Titan ve Dumitrescu, 2014: 1013). "Dış göç", bireyler ya da bazı grupların geçici ya da sürekli olmak kaydıyla kendi vatanlarından ayrılarak başka bir ülkeye yerleşmeleri olarak ifade edilmektedir (Perruchoud ve Redpath-Cross, 2013). Yeni bir iş firsatı yaratma ve daha fazla kazanç elde etmeye yönelik gerçekleştirilen diş göçün temel sebebini büyük oranda ekonomik gerekçeler oluşturmaktadır (Pedersen, Pytlikova ve Smith, 2008: 1170). Göç eylemini gerçekleştiren kişi sayısı kapsamında "bireysel göç", kişinin tek başına ya da sadece aile bireyleriyle gerçekleştirdiği yer değiştirme olarak tanımlanmaktadır. "Kitlesel göç", genellikle savaş ve doğal afet gibi zorunlu sebepler ya da toplumların kendi iradeleri sonucunda büyük bir grup tarafından gerçekleştirilen yer değiştirme eylemidir. İradi bir karar olarak "gönüllü göç" olgusunda devlet ve farklı otoriteler tarafından hiçbir zorlama ya da baskı bulunmadan bireylerin daha kaliteli bir yaşama ulaşma motivasyonları ön plana çıkmaktadır. "Zorunlu göç" sürecinde bireyin iradesi dışında farklı şartlar altında yaşamının ve refahının tehdit altında olması sebebiyle yer değiştirme kararı alınmaktadır (Perruchoud ve Redpath-Cross, 2013). Göç edilen yerde kalma süresine göre sınıflandırılan "geçici göç”, kişi veya grupların üç aydan fazla ancak bir yıldan az olmak suretiyle tatil, ziyaret, iş ve sağlık gibi faktörlerden ötürü yer değiştirmesi olarak ifade edilmektedir. Öte yandan daimî göç ise süre sınırı ve geri dönme düşüncesi olmaksızın kalıcı bir ikamet kararı alınarak gerçekleştirilen yer değiştirme ile karakterizedir. Kendi isteği doğrultusunda başka bir ülke veya bölgeye yerleşmeyi planlayan ve bu doğrultuda belirlenmiş azami koşulları yerine getirme ile fonksiyon gören eylem “düzenli göç", bireylerin legal yolları kullanmadan geçersiz ve sahte evraklarla yasadışı bir şekilde planladıkları göç ise "düzensiz göç” olarak tanımlanmaktadır (Perruchoud ve Redpath-Cross, 2013).

Göçmen, en temel haliyle, göç etme kararını veren ve bu eylemi gerçekleştirmek suretiyle yer/mekân değiştiren kişi olarak tanımlanmaktadır. Göçmenin kendi ülkesinden ya da ikamet ettiği bölgeden ayrılmasının birtakım nedenleri olması sebebiyle göç ettiği toplumda karşılaşacağı tutum ve davranışları öngörmek oldukça güçtür. Göç süreci sonucunda göçmenin tahmin ettiği durumdan daha iyi koşullar ortaya çıkabileceği gibi, kendi beklentilerinin aksine olumsuz yaşam şartları ile karakterize bir dönem de deneyimlenebilmektedir. Göç, çoğunlukla daha önceden hazırlanan planların değişmesine neden olduğu için göçmenlerin ülkelerinden ayrılmadan önceki motivasyonları ve düşünceleri güncel durumla örtüşmeyebilmektedir (Castles ve Miller, 2008: 26). Göçmenlik en genel haliyle, "kültürel dönüşüm süreci olarak kişinin mensubu olduğu topluluğunun normlarının, dĕgerlerinin ve kimliklerinin silindiği, ev sahibi toplumun benzer modellerini kendine uyarlayamadı $\breve{l}$ ve yeni toplumda kabul görmediğini fark ederek giymek zorunda olduğu ateşten bir gömlek" olarak tanımlanabilmektedir (Dlbet, 2008: 314). Göç bazen, göçmenlerin bulundukları koşullardan daha iyilerine erişme isteklerinin olumsuz sonuçlanmasına sebep olurken bazen ise optimal düzeydeki arzuların gerçekleşebileceği alternatif bir yaşam ile neticelenebilmektedir. Aynı zamanda göç bireylere, travmatize edici aktüel olaylardan kaçma ve belirli ölçüde ruhsal açıdan dayanaklı (resilience) ve entegre bir kimlik oluşturma imkânı vermektedir (Giddens ve Sutton, 2016: 102). Bir göçmen olarak mültecilik statüsü, ırk, din ve etnik köken gibi haklı sebepler ve gerekçelerle 


\section{G. DERIN}

bulunduğu vatanda kötü muamele göreceğini düşünerek yaşamakta olduğu ülkeyi terk eden kimselere verilmektedir. Bu statüyü alan kimseler, diplomatik açıdan korunma altına alınmaktadır. Sığınmacı ise, bir göçmen olarak, haklı ve gerekçeli nedenlerden ötürü korkulara sahip olduğunu kanıtlayabilen ancak resmi olarak mültecilik statüsünün tanınmadığı kişilere verilen isimdir (Usanmaz ve Güven, 2013: 150; Öztürk, Erdoğan ve Çalıcı, 2019: 215). Yazının devamında yaşadığı yeri değiştiren kimse için hukuki statüsünden bağımsız ve kapsayıcı bir ifade olarak "göçmen" terimi kullanılacaktır.

Günümüzde geçmişe nazaran belirgin düzeyde azalan silahlı çatışma ve savaşlara rağmen ülke içinde yerinden edilmiş kişiler (internally displaced persons) ve zorunlu göç eden bireylerin sayısında önemli ölçüde artış görülmektedir. Örneğin, Birleşmiş Milletler Mülteciler Yüksek Delegelik Küresel Eğilimler Raporu (United Nations High Commissioner for Refugees Global Trends Report [UNHCR]), 2019 yılı sonunda evrensel olarak 79,5 milyon zorla göç etmek zorunda bırakılmış insan olduğunu (26 milyon mülteci, 45.7 milyon ülke içinde yerinden edilmiş kişi ve 4.2 milyon sığınmacı) ortaya koymaktadır (UNHCR, 2020: 2). Ülke içinde ya da ülkeler arasında gerçeklemesinden bağımsız olarak göçe katılan bireylerin çoğunluğunu sosyal dışlanma, izolasyon, ihmal edilme ve ayrımcılığa maruz kalan kadınlar, çocuklar ve yaşlılar oluşmaktadır. Besin güvenliğinin yeterli ölçüde sağlanamaması, eğitim hizmetindeki aksaklıklar, yiyecek ve su kıtlı̆̆ı, aile kaybı, sosyal destek eksikliği ve göçmenlerin bulunduğu bölgelerin oldukça kalabalık olmasından ekseriyetle ortaya çıkan sağlık sorunları, halihazırda göç sürecini deneyimleyerek travmatize olabilen bireylerin hem olumsuz yaşam dinamikleriyle baş etmesine ket vurmakta hem de daha farklı travmaların gelişmesine sebep olmaktadır (Pedersen, 2015: 15).

\section{Göçün Travmatik Yansımaları}

Sosyo-kültürel değişim, modernleşme, kültürleşme, asimilasyon, stres ve adaptasyon ekseninde yapılan bilimsel çalışmalar, göç olgusu ve travma arasında önemli bir ilişskinin bulunduğunu vurgulamaktadır. Genelde olumsuz yaşam şartları sebebiyle modern şehirlere giden göçmenlerin hayat şartları belirli oranda iyileşme göstermesine rağmen travma ile ilişkili semptom ve bozuklukların sıklığında artış görülebilmektedir (Oytun ve Gündoğar, 2015: 10). Bireylerin göç sırasında ya da sonrasında yaşayabilecekleri işsizlik, gelenek göreneklerden uzak kalma, kendine yabancılaşma, sosyal destekte azalma, aile üyelerinden ayrılma, kültürlerinin belirli bir oranda kaybedilmesi, yeni yerleşim yerinde yalnız hissetme ve iletişim kurmada önemli ölçüde zorlanma gibi birçok sorun, göçmenler tarafindan travmatik bir yaşantı olarak algılanabilmekte ve bu bireyler ruhsal açıdan olumsuz etkilenebilmektedir (Kılınç, Yıldız ve Harmancı, 2017: 183). Göçmenlerin, yerel halk tarafından karşılaşabilecekleri dışlayıcı davranışlar, bu bireylerin hem uyum sürecine hem de savunma mekanizmalarına zarar verebilmektedir (Záleská, Brabcová ve Vacková, 2014).

Göç sürecinin fiziksel sağlığı kötü etkilemesi (Pascoe ve Smart-Richman 2009: 531) ve göçmenlerin toplumla entegrasyonuna ket vuran ayrımcılığa maruz kalması (van Dijk ve ark., 2011: 478), bu bireylerin travmaları ile baş etmelerinde güçlük yaşamalarına neden olmaktadır. Lederbogen ve arkadaşları (2011: 499) damgalanmanın, sosyal dışlanmanın, kültürel yanlış anlamaların/anlaşılmaların ve sözlü iletişim sırasında ortaya çıkan tanısal belirsizliklerin, göçmenlerin sağlık sisteminden alması gereken desteği alamayarak fiziksel ve ruhsal açıdan tam bir iyileşme göstermesine engel olan temel unsurlar olduğunu ifade etmektedir. Kendi ülkelerindeki savaş ve terör gibi kriz yaşantılarından uzaklaşma adına dahil oldukları göç sürecinde ya da ulaşmak istedikleri ülkelere vardıklarında göçmenler, sadece geldikleri yeni kültür ve normlarla karakterize olan toplumla uyum sorunu yaşamamakta aynı zamanda travma sonrası stres bozukluğu, dissosiyatif bozukluk ve somatoform bozukluk gibi kronik psikiyatrik rahatsızlıklar da geliştirebilmektedir (Lindert ve ark., 2009: 251; Hansson ve ark., 2012: 112; Schouler-Ocak, 2015: 6). Wirtgen (2009: 2115), göçmenlerin büyük bir bölümünün, ev sahibi ülkeye geldiklerinde oldukça kötü fiziksel ve 
zihinsel duruma sahip olduklarını bildirmektedir. Göçün travmatik etkileri ile ortaya çıkan olumsuz yaşam dinamiklerinin tedavi edilmesine yönelik bir ihtiyaç ortaya çıktığında gerçekleştirilecek olan krize müdahale psikoterapileri, göç alanında uzman klinik psikolog ve psikiyatristler ya da travma terapistleri tarafından gerçekleştirilmektedir (Priebe ve ark., 2013: 100; Penka, 2013: 30).

Göç gibi toplumsal boyutu olan travmatik olaylar, doğası gereği belirli bir oranda tehlikeli ve zorlayıcı şekilde ortaya çıkabilmektedir. Göçmenler yolculuk esnasında ve göç ettikten sonra şiddet, gasp ve sömürülme gibi birçok zorbalığa maruz kalabilmekte hatta yolculuk sırasında ailelerinin ve arkadaşlarının ölümüne de tanık olabilmektedir. Tüm bu yaşantılar sonucunda göçmenler, şiddetli travmalar deneyimleyebilmektedir (Gün ve Bayraktar, 2008: 170). Papageorgiou ve arkadaşları (2000: 86) tarafından Bosnalı mültecilerle yapılan çalışma, göç sebebiyle ebeveyn kaybı ya da yakın çevrelerinden birisinin ölümüne tanık olan kişilerin daha fazla travmatize olduğu saptanmıştır. Hasanovic (2012: 1) ise 1992-1995 yılları arasındaki savaş nedeniyle göç etmek zorunda kalan 217 genç yetişkin ile yaptığı araştırmayla, savaşın sonlanmasından üç yıl sonra bile göçmenlerin yüksek seviyede travma sonrası stres bozukluğu belirtileri gösterebildiğini ortaya çıkarmıştır. Göçmenlerin bu olumsuz durumlarla karşılaşmaları neticesinde korku, çaresizlik, anguaz (angoisse), depresif duygulanım, öfke, suçluluk duygusu, tiksinme, utanç, benlik saygısında azalma, dissosiyatif reaksiyonlar ve kimlik sorunları gibi travmanın en belirgin emosyonel tepkileri oluşmaktadır. Özellikle zorunlu göç eden ya da göç etmeye sürüklenen travmatize kişilerde ortaya çıkan emosyonel tepkilerin yanı sıra dissosiyatif bozukluk, travma sonrası stres bozukluğu veya sınırda kişilik bozukluğu gibi psikopatolojik durumlar da oluşabilmektedir (Öztürk, 2018: 34, 2020a: 117). Göç kökenli olumsuz yaşam dinamikleri sonucunda bireyler hem geçmiş bireysel travmatik yaşantıları hem ayrılmak zorunda kaldıkları ülkedeki toplumsal travmaları hem de geldikleri yeni ülkedeki uyumsal sorunlar ve karşılaşabilecekleri olağan hayatın güçlükleri ile mücadele etmek zorunda kalmaktadır. Çok eksenli, kronik ve kompleks bir travmatik yaşantı olarak "göç", bütüncül bir perspektifle değerlendirmeli ve bu süreç ile ilişkili ortaya çıkabilen psikopatolojilerde bu olgu majör bir faktör olarak çalışılmalıdır (Öztürk, 2020a: 116; Öztürk ve Şar, 2016: 3).

\section{Göçmenlerde Travma Kökenli Psikopatolojilerin Prevalansı}

Savaş, çatışma ve terör gibi ruhsal bütünlüğü negatif yönde etkileyen olaylar sebebiyle ülkelerinden kaçmak zorunda kalan göçmenlerde hem göçün travmatik doğası hem de vatanlarından uzaklaşmalarına neden olan olumsuz olaylardan ötürü başta travma sonrası stres bozukluğu ve dissosiyatif bozukluklar olmak üzere birçok psikopatoloji gelişebilmektedir (Aichberger, 2015: 35). Finklestein ve Solomon (2009: 38) tarafindan İsrail'deki üç farklı göçmen grubundaki travma sonrası stres bozukluğu ve dissosiyatif yaşantıların sıklığına ilişkin yapılan çalışmada travma sonrası stres bozukluğu prevalansının yüzde 15-27, dissosiyatif semptomların sıklığının ise yüzde 15-23 arasında değişim gösterdiği ortaya çıkmıştır. Aynı çalışmada üç göçmen grubundaki katılımcıların Dissosiyatif Yaşantılar Ölçeği (DES) toplam puan ortalaması 17 bulunmuş olup bu skor subklinik düzeyde dissosiyatif yaşantıların varlığına işaret etmektedir. Silove ve arkadaşları (1997: 354) tarafından sı̆̆ınmacılar ile yapılan çalışmada ise katılımcıların yüzde 79'unun cinayete tanık olma, saldırıya ve işkenceye maruz kalma gibi en az bir travmatik olaya maruz kaldığı, yüzde 37'sinin ise travma sonrası stres bozukluğu tanı kriterlerini karşıladığı belirlenmiştir. Savaş sonrası İsveç'e gelen 77 göçmenle yapılan bir çalışmada, travma sonrası stres bozukluğu tanı kriterlerini karşılama oranı \%71, dissosiyatif bozuklukların yaygınlığ 1 ise \%36 olarak belirlenmiştir (Gušić ve ark., 2017: 1135).

Göçün psikolojik etkilerine yönelik yapılan birçok çalışma, göçmenlerdeki travma sonrası stres bozukluğu oranının, göç edilen ülkenin genel nüfusa oranla on kat daha yüksek olduğuna işaret etmektedir (Fazel, Wheeler ve Danesh, 2005: 1310; Crumlish ve O'Rourke, 2010: 240). Göçmenlerdeki travma sonrası stres bozukluğunun prevalansına ilişkin araştırmalar, yüzde 3-86 


\section{G. DERIN}

arasında oldukça geniş bir uzamda seyreden oranları ortaya koymaktadır. Savaş ve çatışmaların yoğun olduğu kriz bölgelerinden kaçış, fiziksel istismar, aile üyelerinin kaybı ve işkence en sık görülen travmatik yaşantıları oluşturmaktadır. Göçmenler ve ruh sağlığı kapsamında gerçekleştirilen bir meta analiz çalışmasında, göç etmek zorunda kalan bireylerdeki ruhsal bozukluk oranının (\%40), ekonomik nedenlerle göç edenlere (\%21) kıyasla iki kat daha yüksek olduğu belirlenmiştir (Lindert ve ark., 2009: 250). Güneydoğu Asya, eski Yugoslavya, Orta Doğu ve Orta Amerika'daki yedi ülkedeki toplam 6.743 göçmen ile yapılan yirmi araştırmanın sonucuna göre bu bireylerdeki travma sonrası stres bozukluğunun prevalansı \%9 olarak bulunmuştur (Fazel, Wheeler ve Danesh, 2005: 1311). Steel ve arkadaşları (2009: 540) tarafından yürütülen meta analiz çalışmasına 1980-2009 yılları arasında 18 yaş üzerindeki 64.332 göçmen ile yapılan araştırmalar dahil edilmiş olup bu çalışmalardaki travma sonrası stres bozukluğu yaygınlığı yüzde 30.6, işkenceye maruz kalma ise yüzde 21.0 oranında tespit edilmiştir. Cardozo ve arkadaşları (2000: 571), 1999'daki Kosova savaşı ile ilgili Arnavut göçmenlerdeki travma sonrası stres bozukluğu oranının yüzde 17.1, genel psikiyatrik morbidite prevalansının ise yüzde 43 olduğunu saptamıştır.

\section{Gelişimsel Göç ve Göçün Psikojen Pompa Etkisi}

Göç sürecinde bazen göçmenlerin beklentilerin aksine negatif yönde değişimler bazense göçmenlerin öngördüğü üzere pozitif yönde değişimler gerçekleşebilmektedir. Göçmenler adına göç sürecinin temel hedefi bireylerin kuşaklararası düzeyde daha iyi bir yaşama ulaşma isteğidir. Psikotarihsel perspektif doğrultusunda göçler "psikojen pompa etkisi” yaratmaktadır (DeMause, 1997: 112). Öztürk (2020a: 53), kişinin içinde yaşadığı çağ dışı dinamiklerden kurtulmasını sağlayacak türde olan ve onun potansiyellerini kullanabilmesine imkân tanıyan şehir ya da ülke değişimlerini, bireyin pozitif bir yeniden yapılanmasına hizmet edeceğinden dolayı "gelişimsel göç" olarak değerlendirmektedir. Bir toplumda yenilenmenin ve yenilenerek artık işe yaramayan baş etme stratejilerinin ve yanlış çocuk yetiştirme stillerinin, geçmişte ya da önceki yaşanılan yere bırakılabilmesini, ancak büyük ve dramatik göçler sağlayabilmektedir. Toplumların kendi içinden yetişen ileri bir kesimin ortalamayı aşarak göç olgularındaki gibi kırılma yaratması çok olağan bir yaşam deneyimi olmadığından dolayı ülkeler büyük ihtimalle bu nedenle göçe bu kadar büyük bir oranda izin vermektedirler. Göç eden binlerce kişiden bazıları travmatik yaşantılarını ve dissosiyatif reaksiyonlarını geçmişinde ya da o anda yaşadığı yerde bırakarak hem kendi hem de insanlık tarihinin gelişimi adına büyük adım atacaklardır ki bu büyük adımlar kuşaklar boyunca pozitif yönde etkilerini göstermeye devam edecektir. Büyük göçler sonrasında ortaya çıkan kültürel kopmalar, ileriye yönelik adım atmak isteyen ailelerin önünü açar ve yeni bir toplumda yeni bir insan ve aile tipinin oluşturulmasını gerçekleştirebilirler (Öztürk, 2016: 30; 2020a: 53; 2020b: 12).

\section{SONUÇ}

Çok boyutlu ve kompleks bir fenomen olarak göç sürecinde klinik psikoloji ve psikiyatri alanlarında gerçekleştirilen hem ulusal hem de uluslararası düzeydeki araştırmalar ile disiplinler arası çalışmalar, göçmenlerin ait oldukları toplumların stabil olmayan dinamiklerinden, yaşanan savaş/çatışma gibi şiddet temelli olaylardan ve bireylerin yaşadıkları ülkedeki güvenlik ve refah düzeyi ile ilişkili sorunlarından ötürü kendi isteğiyle ya da zorunlu olarak bölge veya ülke değiştirdiklerini göstermektedir. Günümüzde göçün belirli oranda kriz yaşantısıyla deneyimlenmesi ve bu sürecin bireylerin ruh sağlığı üzerindeki olumsuz etkilerinin iyi bilinen bir fenomen olması sebebiyle göçmenlerle çalışan psikolog, psikiyatrist ve sosyal çalışmacılar gibi psiko-sosyal destek uzmanlarının önemi oldukça artmıştır (Öztürk, Erdoğan ve Çalıcı, 2019: 220). Göç alanında çalışan ruh sağlığı uzmanları ve akademisyenler, kendi iradeleri dışında yer değiştirmek zorunda kalan göçmenlerin, travma sonrası stres bozukluğu ve dissosiyatif bozukluklar başta olmak üzere psikiyatrik bir tanıya sahip olma açısından en savunmasız ve en yüksek riskli gruplardan biri olduğunu vurgulamaktadır (Bhugra ve ark., 2014: 110). Hem göç süreci sebebiyle ortaya çıkabilen 
travmaların optimal sürede tedavi edilebilmesi hem de göçmenlerin ev sahibi toplumla ve kültürle olan entegrasyonlarının sağlanabilmesi hususlarında ülkelerin benimseyeceği bütüncül müdahale önemli ve temel bir konuma sahiptir. Bu eksende Moon (2009: 80), "terapötik ahlaki düzen (therapeutic moral order)" kavramını ortaya atarak sadece savaş, çatışma ve terör gibi göçe sebep olan temel olayların göçmenler üzerindeki etkilerine odaklanılmaktan ziyade küreselleşme ve sosyolojik değişimleri de içeren makro bir perspektif ile yerinden edilen insanlara yönelik terapötik yönelimli ahlaki düzen kurulması gerektiğini ifade etmektedir. Terapötik ahlaki düzen kapsamında Pederson (2015: 15), ulusal ve uluslararası sağlık sorunlarının makro düzeyde değerlendirilmesinin, göçmenlerin hem toplumla olan entegrasyonlarının sağlanmasına hem de bireylerin ruhsal bütünlüğünün korunmasına katkı sağlayacağını vurgulamaktadır.

Göçmenlere dair devletlerin izlediği strateji ve politikalar, bu grubun toplumla olan entegrasyonlarının en kısa sürede sağlanması ve psikolojik desteğin uygun koşullar altında verilmesi temel alınarak planlanmakta ve yürütülmektedir. Kapsayıcı ve destekleyici göç stratejilerinin toplumlar nezdinde yaygınlaşması ve göç olgusunun hem pozitif hem de negatif unsurlarına yönelik verilecek bütüncül eğitim çalışmalarıyla, göç alan ülkelerde göçmenler ve ev sahibi bireyler arasındaki uyum ve bütünleşmenin önemli oranda gelişebileceği ve nihayetinde entegre bir toplumsal yapının oluşabileceği düşünülmektedir. Yeniden vurgulanmak istendiği üzere büyük göçler sonrasında ortaya çıkan kültürel kopmalar, ileriye yönelik adım atmak isteyen ailelerin önünü açar ve yeni bir toplumda yeni bir insan ve aile tipinin oluşturulmasını gerçekleştirebilirler.

\section{KAYNAKÇA}

Aichberger, M. C. (2015). The Epidemiology of Post-traumatic Stress Disorder: A Focus on Refugee and Immigrant Populations. Trauma and Migration. (Ed. M. Schouler-Ocak. M). Springer, Cham. s. 33-37.

Bhugra, D., Gupta, S., Schouler-Ocak, M., Graeff-Calliess, I., Deakin, N. A., Qureshi, A., ... \& Till, A. (2014). EPA guidance mental health care of migrants. European Psychiatry, 29(2), 107115.

Cardozo, B. L., Vergara, A., Agani, F., \& Gotway, C. A. (2000). Mental health, social functioning, and attitudes of Kosovar Albanians following the war in Kosovo. Jama, 284(5), 569577.

Castles, S., \& Miller, M. J. (2008). Göçmenlerin Kimlik Arayışı: Konuk İşçilikten Yerleşik Göçmenliğe. İstanbul: Endülüs Yayınları. s.24-41.

Crumlish, N., \& O'Rourke, K. (2010). A systematic review of treatments for post-traumatic stress disorder among refugees and asylum-seekers. The Journal of nervous and mental disease, 198(4), 237-251.

DeMause, L. (1997). The psychogenic theory of history. The Journal of Psychohistory, 25(2), 112.

Dlbet, F. (2008). Göç. Modern Toplumsal Düşünce Sözlüğ̈̈. (Ed. Outhwaite, W). İstanbul: İletişim Yayınları. s. 314-315.

Ekici, S., \& Tuncel, G. (2015). Göç ve insan. Birey ve Toplum Sosyal Bilimler Dergisi, 5(1), $9-22$.

Fazel, M., Wheeler, J., \& Danesh, J. (2005). Prevalence of serious mental disorder in 7000 refugees resettled in western countries: a systematic review. The Lancet, 365(9467), 1309-1314. 


\section{G. DERIN}

Finklestein, M., \& Solomon, Z. (2009). Cumulative trauma, PTSD and dissociation among Ethiopian refugees in Israel. Journal of Trauma \& Dissociation, 10(1), 38-56.

Gheasi, M., \& Nijkamp, P. (2017). A brief overview of international migration motives and impacts, with specific reference to FDI. Economies, 5(3), 31.

Giddens, A., \& Sutton, P. W. (2016). Sosyolojide Temel Kavramlar (Çev. A. Esgin). Ankara: Phoenix Yayınları. s. 93-134.

Gušić, S., Cardeña, E., Bengtsson, H., \& Søndergaard, H. P. (2017). Dissociative experiences and trauma exposure among newly arrived and settled young war refugees. Journal of Aggression, Maltreatment \& Trauma, 26(10), 1132-1149.

Gün, Z., \& Bayraktar, F. (2008). Türkiye'de İç Göçün Ergenlerin Uyumundaki Rolü. Turk Psikiyatri Dergisi, 19(2), 167-176.

Hansson, E. K., Tuck, A., Lurie, S., \& McKenzie, K. (2012). Rates of mental illness and suicidality in immigrant, refugee, ethnocultural, and racialized groups in Canada: a review of the literature. The Canadian Journal of Psychiatry, 57(2), 111-121.

Hasanovic, M. (2012). P-969-Posttraumatic stress disorder of bosnian internally displaced and refugee adolescents from three different regions after the war 1992-1995 in bosniaherzegovina. European Psychiatry, 27, 1.

Kılınç, G., Yıldız, E., \& Harmancı, P. (2017). Toplumsal travmatik olaylar ve aile ruh sağlığı. Turkiye Klinikleri Psychiatric Nursing-Special Topics, 3(2), 182-188.

Laban, C. J., Komproe, I. H., Gernaat, H. B., \& de Jong, J. T. (2008). The impact of a long asylum procedure on quality of life, disability and physical health in Iraqi asylum seekers in the Netherlands. Social psychiatry and psychiatric epidemiology, 43(7), 507.

Lederbogen, F., Kirsch, P., Haddad, L., Streit, F., Tost, H., Schuch, P., ... \& MeyerLindenberg, A. (2011). City living and urban upbringing affect neural social stress processing in humans. Nature, 474(7352), 498-501.

Lindert, J., von Ehrenstein, O. S., Priebe, S., Mielck, A., \& Brähler, E. (2009). Depression and anxiety in labor migrants and refugees-a systematic review and meta-analysis. Social science \& medicine, 69(2), 246-257.

Moon, C. (2009). Healing past violence: Traumatic assumptions and therapeutic interventions in war and reconciliation. Journal of Human Rights, 8(1), 71-91.

Otoiu, A., Titan, E., \& Dumitrescu, R. (2014). Internal and international migration: Is a dichotomous approach justified?. Procedia-Social and Behavioral Sciences, 109, 1011-1015.

Oytun, O., \& Gündoğar, S. S. (2015). Suriyeli sığınmacıların Türkiye’ye etkileri raporu. Orsam-Tesev Rapor, (195), 1-40.

Öztürk, E. (2016). Psikotarih açısından çocuk yetiştirme tarzları ve çocuk istismarı. Turkiye Klinikleri Journal of Forensic Medicine-Special Topics, 2(3), 24-34.

Öztürk, E. (2018). Travma Merkezli Alyans Model Terapi: Dissosiyatif Kimlik Bozukluğunun Psikoterapisi. Ruhsal Travma ve Dissosiyasyon. (Ed. E. Öztürk). Ankara: Türkiye Klinikleri. s. 31-38.

Öztürk, E. (2020a). Travma ve Dissosiyasyon: Psikotravmatoloji Temel Kitabı (2. Bask1). İstanbul: Nobel Tip Kitabevi. 33-128. 
Öztürk, E. (2020b). Psikotarih, travma ve dissosiyasyon: Çocukluk çağı travmaları, savaşlar ve dissosiyasyonun anamnezi. Psikotarih (Ed. E. Öztürk). 1. Baskı. Ankara: Türkiye Klinikleri. s.121.

Öztürk, E., Erdoğan, B., \& Çalıc1, C. (2019). Göçmenler ve Ruh Sağlı̆̆ı Göçmenler ve Göç Süreci: Psikotravmatolojik Bir Değerlendirme. Türkiye'de Göçmen Kapsayıcılı̆̆ı: Sorundan Fırsata Dönüşüm Önerileri (Ed. H. Sakız - H. Apak). Ankara: Pegem Akademi. s. 213-226.

Öztürk, E., \& Şar V. (2016) The trauma-self and its resistances in psychotherapy. J Psychol Clin Psychiatry. 6(6), 1-7.

Pascoe, E. A., \& Smart Richman, L. (2009). Perceived discrimination and health: a metaanalytic review. Psychological bulletin, 135(4), 531.

Papageorgiou, V., Frangou-Garunovic, A., Iordanidou, R., Yule, W., Smith, P., \& Vostanis, P. (2000). War trauma and psychopathology in Bosnian refugee children. European child \& adolescent psychiatry, 9(2), 84-90.

Pedersen, D. (2015). Rethinking trauma as a global challenge. Trauma and Migration. (Ed. M. Schouler-Ocak). Springer, Cham. s. 9-31.

Pedersen, P. J., Pytlikova, M., \& Smith, N. (2008). Selection and network effects-Migration flows into OECD countries 1990-2000. European Economic Review, 52(7), 1160-1186.

Penka, S. (2013). Zugangsbarrieren von Personen mit Migrationshintergrund zum Suchthilfesystem-Konsequenzen für die Praxis. Sucht und Migration. Freiburg im Breisgau: Lambertus, 27-46.

Perruchoud, R., \& Redpath-Cross, J. (2013). Uluslararası Göç Hukuku, Göç Terimleri Sözlügü. Uluslararası Göç Örgütü (IOM) Yayınları, (31).

Priebe, S., Matanov, A., Barros, H., Canavan, R., Gabor, E., Greacen, T., ... \& Díaz-Olalla, J. M. (2013). Mental health-care provision for marginalized groups across Europe: findings from the PROMO study. The European Journal of Public Health, 23(1), 97-103.

Schouler-Ocak, M. (2015). Introduction: The relevance of trauma among immigrants. Trauma and Migration. (Ed. M. Schouler-Ocak). Springer, Cham. s. 3-8.

Silove, D., Sinnerbrink, I., Field, A., Manicavasagar, V., \& Steel, Z. (1997). Anxiety, depression and PTSD in asylum-seekers: assocations with pre-migration trauma and post-migration stressors. The British Journal of Psychiatry, 170(4), 351-357.

Steel, Z., Chey, T., Silove, D., Marnane, C., Bryant, R. A., \& Van Ommeren, M. (2009). Association of torture and other potentially traumatic events with mental health outcomes among populations exposed to mass conflict and displacement: a systematic review and meta-analysis. Jama, 302(5), 537-549.

Şentürk, Ü. (2019). Göçmenlik ve Sosyal Politika. Türkiye'de Göçmen Kapsayıcılı̆̆ı: Sorundan Fırsata Dönüşüm Önerileri. (Ed. H. Sakız - H. Apak). Ankara: Pegem Akademi. s. 1746.

UNHCR, (2020). 2019 Global trends: refugees, asylum-seekers, returnees, internally displaced and stateless persons. UNHCR, Geneva. s. 1-15.

Usanmaz, G., \& Güven, S. (2013). Türkiye'de Mültecilik Olgusu ve Festus Okey Vakas1. Ankara Üniversitesi SBF Dergisi, 68, 143-167. 
van Dijk, T. K., Agyemang, C., de Wit, M., \& Hosper, K. (2011). The relationship between perceived discrimination and depressive symptoms among young Turkish-Dutch and MoroccanDutch. The European Journal of Public Health, 21(4), 477-483.

Wirtgen, W. (2009). Traumatisierte Flüchtlinge: Psychische Probleme bleiben meist unerkannt. Deutsches Arzteblatt-Arztliche Mitteilungen-Ausgabe B, 106(49), 2115.

Yazıcı, M. (2019). Bir Toplumsal Yapı Değişim Dinamiği Olarak Göçler ve Göçmenler. Türkiye'de Gö̧̈men Kapsayıcllı̆̆l: Sorundan Fırsata Dönüşüm Önerileri. (Ed. H. Sakız - H. Apak). Ankara: Pegem Akademi. s. 71-98.

Záleská, V., Brabcová, I., \& Vacková, J. (2014). Migration and its impact on mental and physical health: social support and its main functions. Kontakt, 16(4), e236-e241. 